\title{
Study of Glycemic Control by Ketogenic Diet Supplemented with Different Oils in Type II Diabetic Rats
}

\author{
Shaimaa H. Negm ${ }^{1}$ \\ 1: Home Economic Dept., Specific Education Faculty, Port Said University, \\ Egypt.
}

\begin{abstract}
In recent years, very low carbohydrate ketogenic diets (VLCKD) have been emphasized. While commonly debated and often opposed, these are clearly successful as a method for treating obesity, hyperlipidemia and diabetes at least in the short to medium term. Therefore, this research was conducted to investigate the impact of ketogenic diet (KD) supplemented with oil of either grape seed or fish and virgin olive on diabetic rats. Forty eight male albino rats weighing 200 to $210 \mathrm{~g}$, were assigned into two main groups. The first group $(n=8)$ was control negative group $(-v e)$, the second main group $(n=40)$ were intraperitoneally injected with a single dose of streptozotocin (STZ) $[60 \mathrm{mg} / \mathrm{kg}$ b.w.] for induction of diabetes, then these rats were divided into five subgroups. Subgroup one was fed on the basal diet and served as a control positive group, while subgroup 2 was fed on KD only and subgroups from 3 to 5 were fed on KD supplemented with $4 \%$ oil of either grape seed or fish and virgin olive, respectively for 8 weeks. The results indicated that, STZ treated rats showed significant reduction $(\mathrm{P} \leq 0.05)$ in serum insulin concentration and increased glucose levels compared to normal rats. KD supplemented with oil of either grape seed or fish and virgin olive improved the biochemical changes due to diabetes. Furthermore, the intervention caused favorable changes in blood lipids and restored liver and kidney functions of the treated rats compared to the control positive group. In conclusion, the ketogenic diet and KD supplemented with oil of either grape seed or fish or virgin olive are potentially promising diets for diabetic patients.
\end{abstract}

Keywords: Ketogenic diet, diabetes mellitus, grape seed oil, fish oil, virgin olive oil. 


\section{INTRODUCTION}

In recent decades, the global prevalence of obesity and type 2 diabetes has increased significantly leading to a global epidemic (NRFC, 2016 and Gregg and Shaw, 2017). Globalization, economic development, an increase in sedentary lifestyles, the use of some medications and the dietary transition to high-calorie and processed foods led to this phenomenon (Piaggi et al., 2018). High intakes of carbohydrates have recently been associated with a higher risk of total mortality, although lower overall mortality has been correlated with total fat and different forms of fat (Dehghan et al., 2017). Consequently, managing obesity and its associated comorbidities has thus become one of the most important issues nowadays.

A ketogenic diet (KD) is a diet rich in fat, sufficient in protein and low in carbohydrates, and known to induce and maintain a kenotic state by generating high levels of ketogenic bodies through fat metabolism (Boison, 2017). Over the past decades, $K D$ has been extended to other neurological or non-neurological diseases and its beneficial effects have been demonstrated (Koppel and Swerdlow, 2018). In particular, KD is one of the most used dietary therapies in recent clinical trials for patients with diabetes or obesity (Abbasi, 2018).

Efficient dietary approaches to avoid and mitigate these changes include the use of such bioactive compounds as vegetable oils, fish oils and the use of polyphenolic compounds as antioxidants for preventive strategies (Naveen and Baskaran, 2018). Grape seed oil (GSO) is a vegetable oil extracted from the grape seeds which consists of up to 7-20\% oil (Matthaus,2008). GSO has recently shown to have several health properties due to its contents of polyphenols, flavonoids and vitamins E and C (Ranjbar-Zahedani et al., 2015). GSO also contains high levels of unsaturated fatty acids (UFA) and low levels of saturated fatty acids (SFA), as well as high percentage of linoleic acid. GSO may improve insulin resistance in human (Irandoost et al., 2013). It can serve as an important alternative medicinal drug to reduce $\beta$-cell dysfunction (Lai et al., 2014). GSO also has been shown to decrease plasma triglycerides and cholesterol (Javadi et al., 2014). Moreover, the GSO phenolic compounds and antioxidants act to reduce the oxidative stress (Wang et al., 2015).

Marine omega-3 polyunsaturated fatty acids (PUFAs) have demonstrated protective effects against dietary metabolic changes, including dyslipidemia, insulin resistance (Taltavull et al., 2016), and obesity (AlbrachtSchulte et al., 2018). Fish oil (FO) consumption can decrease the level of free 
fatty acids, improve the lipid profile and insulin sensitivity and reduce the incidence of type 2 diabetes (Albert et al., 2014).

Virgin Olive oil (VOO) is a functional food with a high content of mono unsaturated fatty acids (MUFA), plus 1\% omega-3 PUFA, $73.3 \%$ oleic acid (MUFA), $7.9 \%$ omega-6 PUFA, and $13.5 \%$ saturated fatty acids (SFA) (Psaltopoulou et al., 2011). It also includes other minor elements, biologically active, such as polyphenols (Covas et al., 2006). The phenolic compounds are essential in stimulating the blood insulin secretion, and this is due to the oleuropein found in olive oil and its role in triggering and releasing insulin and increasing cell glucose intake (Gonzalez, 2007). The phenolic compounds of olive oil have antioxidant properties and also have beneficial effects on various physiological parameters, such as atherosclerosis, obesity, metabolic syndrome, type II diabetes and also has significant influence on lipid metabolism (Ambra et al., 2017). So, the aim of the present study was to improve and modify the ketogenic diet by replacing the animal fats by vegetable oils to reduce the bad effects of the traditional ketogenic regimen, Also, the effect of ketogenic diet supplemented with oil of either grape seed or fish or virgin olive on diabetic rats was studied.

\section{Materials and methods}

\section{Materials}

- Grape seed oil and Virgin olive oil were obtained from Food Technology Research Institute, Agricultural Research Center, Giza, Egypt. Fish oil was obtained from Egyptian Indian Company for Natural Products.

- Chemicals: Casein, vitamins, minerals, cellulose, choline chloride and Streptozotocin (STZ) were bought from El- Gomhoria Company, Cairo, Egypt. Kits for biochemical analysis were purchased from Biodiagnostic Company for Pharmaceutical and Chemicals, Dokki, Egypt.

- Animals: Forty eight healthy male albino rats (Sprague-Dawley strain) were bought from the Helwan Experimental Animals Station at the age of eight weeks (200 to 210 g.).

\section{Methods:}

Induction of animal model of diabetes: Diabetes was induced by a single intraperitoneal injection of freshly prepared STZ $(60 \mathrm{mg} / \mathrm{kg} \mathrm{b.w}$.) dissolved in $0.1 \mathrm{~mol} / 1$ citrate buffer of PH 4.5 (Al-Hariri, 2012). Three days later, the level of the blood glucose was assessed and the level $\geq 250 \mathrm{mg} / \mathrm{dl}$ was considered as diabetic (Ghauri et al .,2020). 


\section{Experimental Animal Design}

Forty eight male albino rats were housed in well aerated cages under hygienic conditions and fed on basal diet for one week for adaptation according to (Reeves et al., 1993). After this week rats were divided into two main groups as follows:- The first main group $(n=8)$ was kept as control negative group, the second main group $(n=40)$ was intraperitoneally injected with a single dose of STZ [60 mg/kg b.w.] for induction of diabetes, then these rats were divided into five subgroups (8 rats each). Subgroup one was fed on the basal diet and served as a control positive group, subgroup 2 was fed on ketogenic diet only (standard diet) as shown in table (1) (Nylen et al., 2005). Subgroups from 3 to 5 were fed on Ketogenic diet supplemented with $4 \%$ oil of (grape seed, fish and virgin olive) respectively.

At the end of the study ( 8 weeks) the rats were fasted for 12 hours, and then sacrificed under ether anesthesia. Blood samples were obtained from suborbital vein of rats by means of fine capillary glass tubes in a centrifuge tube without any anticoagulant and centrifuged for 20 minutes at 3000 r.p.m. to obtain serum after being left at room temperature for complete clotting.

Table 1. Nutrient composition of basal diet and ketogenic diet

\begin{tabular}{|l|c|c|c|}
\hline \multirow{2}{*}{ Nutrients } & Basal diet $(\mathbf{g} / \mathbf{k g})$ & \multicolumn{2}{c|}{ Ketogenic diet } \\
\cline { 3 - 4 } & & $\mathbf{( g / k g )}$ & $\mathbf{\%}$ \\
\hline Protein (Casein) 20\% & 200 & 142.090 & 16.6 \\
\hline Carbohydrate (starch) & 665 & 4.887 & 3.4 \\
\hline Fat ( Corn oil) & 40 & 737.83 & 80 \\
\hline Vitamins mixture & 10 & \multicolumn{2}{|c|}{4.611} \\
\hline Minerals mixture & 35 & \multicolumn{2}{|c|}{44.472} \\
\hline Fiber & 50 & \multicolumn{2}{|c|}{66.087} \\
\hline Choline bitartrate & 2.5 & \multicolumn{2}{|}{} \\
\hline L-Cystine & 1.8 & \multicolumn{2}{|c|}{} \\
\hline
\end{tabular}

\section{Biochemical analysis:}

Serum was analyzed for the following biochemical parameters: Insulin activity was estimated using enzyme linked immunosorbent assay ELISA method as described by Clark and Hales, (1994). Glucose level was determined according to Burrin and Price, (1985). Serum aspartate aminotransferase (AST) and alanine aminotransferase (ALT) were measured according to Bergmeyer et al. (1978). The level of urea and creatinine in serum was estimated spectrophotometrically as described by Patton and Crouch, (1977) and Larsen, (1972), respectively. Lipid parameters were determined as follows; Triglyceride (TG) according to Fossati and Prencipe, (1982), total cholesterol (TC) by the method of Allian et al. (1974), high 
density lipoprotein- cholesterol (HDL-C) by the method of Albers et al. (1983). Calculation of low density lipoprotein-cholesterol (LDL-C) and very low density lipoprotein-cholesterol (VLDL-C) was done according to the equation of Wallach, (1992). Low density lipoprotein-cholesterol can be calculated as follows: LDL-C $=$ Total cholesterol - HDL-C - VLDL-C Fruchart (1982). Where VLDL $=$ triglycerides $/ 5$ Statistical analyses:

The results were expressed as mean \pm standard error (SE) and were analyzed statistically using one-way analysis of variance ANOVA. The results were considered significant at $\mathrm{P} \leq 0.05$. Calculations were made by SPSS software version 20 (SPSS Inc., Chicago, Illinois, USA) (Emsley et al., 2010).

\section{Results:}

Rats injected with $\mathrm{STZ}$ had significant $(\mathrm{P} \leq 0.05)$ higher glucose level but had significant $(\mathrm{P} \leq 0.05)$ lower insulin concentration, compared to the control negative group Table (2). Feeding diabetic rats on ketogenic diet only or ketogenic diet supplemented with oils of either grape seed or fish or olive caused a significant $(\mathrm{P} \leq 0.05)$ decrease in the elevated serum glucose level, compared to the control positive group. It was clear that, no significant difference in glucose level among the treated groups with ketogenic diet supplemented with different oils. However, there was a significant difference in serum glucose between the diabetic rats that were fed on ketogenic diet only and the other diabetic rats that fed on ketogenic diet and supplemented with the different oils. The administration with ketogenic diet to diabetic rats caused a significant $(\mathrm{P} \leq 0.05)$ reduction in glucose level compared to the control positive group.

The percent of glucose reduction as a result of feeding ketogenic diet only or ketogenic diet supplemented with oils (grape seed, fish, virgin olive) are $12.72 \%, 41.00 \%, 41.88$ and $42.37 \%$ respectively, as compared to the value of glucose level in the control positive group. Ketogenic diet supplemented with olive oil caused the highest reduction in glucose level. Regarding to insulin concentration, it was significantly higher in the treated groups with ketogenic diet only or ketogenic diet supplemented with different oils compared to the control diabetic group. Moreover, no significant difference in insulin activity level among the treated groups was noticed. It was obvious that, the treatments with ketogenic diet supplemented with fish oil caused the highest beneficial effect in improving in insulin level. 
Table (2): Effect of ketogenic diet on serum glucose and insulin levels of diabetic rats.

\begin{tabular}{|l|c|c|l|}
\hline \multicolumn{1}{|c|}{ Parameters } & $\begin{array}{l}\text { Glucose } \\
\text { (mg/dl ) }\end{array}$ & $\begin{array}{l}\text { \%oof } \\
\text { glucose } \\
\text { reduction }\end{array}$ & $\begin{array}{l}\text { Insulin } \\
(\mathbf{m I U} / \mathbf{m l})\end{array}$ \\
\hline Control (-ve) & $81.00 \pm 1.76^{\mathrm{d}}$ & - & $16.57 \pm 0.77^{\mathrm{a}}$ \\
\hline Control (+ve) & $274.40 \pm 3.50^{\mathrm{a}}$ & - & $7.21 \pm 0.62^{\mathrm{c}}$ \\
\hline Diabetic+ keto diet & $178.40 \pm 3.70^{\mathrm{b}}$ & 34.99 & $9.25 \pm 0.60^{\mathrm{b}}$ \\
\hline $\begin{array}{l}\text { Diabetic+ keto diet ( grape seed } \\
\text { oil) }\end{array}$ & $120.60 \pm 2.06^{\mathrm{c}}$ & 56.05 & $9.37 \pm 0.21^{\mathrm{b}}$ \\
\hline Diabetic+ keto diet (fish oil) & $118.80 \pm 1.88^{\mathrm{c}}$ & 56.71 & $11.18 \pm 0.87^{\mathrm{b}}$ \\
\hline $\begin{array}{l}\text { Diabetic+ keto diet (virgin olive } \\
\text { oil) }\end{array}$ & $117.80 \pm 7.10^{\mathrm{c}}$ & 57.07 & $10.19 \pm 0.65^{\mathrm{b}}$ \\
\hline
\end{tabular}

Values were expressed as Means \pm SE.

Values at the same column with different letters are significant at $\mathrm{P} \leq 0.05$.

Table (3) illustrates the effect of ketogenic diet supplemented with oils of either grape seed or fish or virgin olive on liver functions of normal and diabetic rats. The activities of serum AST and ALT were significantly increased $(\mathrm{P} \leq 0.05)$ in the diabetic control group, compared with the corresponding value of normal control group. Supplementation with ketogenic diet only or ketogenic diet supplemented with different oils significantly decreased $(\mathrm{P} \leq 0.05)$ the elevated activity of both serum AST and ALT compared to the positive control group. Moreover, there is no significant difference in serum AST and ALT among the three treated groups with ketogenic diet supplemented with oils of either grape seed or fish or virgin olive.

Table (3): Effect of ketogenic diets on liver function of diabetic rats.

\begin{tabular}{|c|c|c|}
\hline \multirow[t]{2}{*}{ Parameters } & AST & ALT \\
\hline & \multicolumn{2}{|c|}{$(\mathbf{U} / \mathbf{L})$} \\
\hline Control (-ve) & $118.40 \pm 1.63^{\mathrm{d}}$ & $93.40 \pm 2.98^{\mathrm{d}}$ \\
\hline Control (+ve) & $146.60 \pm 2.75^{\mathrm{a}}$ & $129.80 \pm 2.89^{\mathrm{a}}$ \\
\hline Diabetic+ keto diet & $134.00 \pm 2.77^{b}$ & $117.60 \pm 3.61^{b}$ \\
\hline Diabetic+ keto diet ( grape seed oil) & $126.00 \pm 1.14^{\mathrm{c}}$ & $103.60 \pm 2.44^{\mathrm{c}}$ \\
\hline Diabetic+ keto diet ( fish oil) & $124.80 \pm 3.12^{\text {cd }}$ & $101.40 \pm 2.56^{\text {cd }}$ \\
\hline Diabetic+ keto diet ( olive oil) & $122.00 \pm 1.64^{\text {cd }}$ & $107.20 \pm 3.06^{\mathrm{c}}$ \\
\hline
\end{tabular}

Values were expressed as Means \pm SE.

Values at the same column with different letters are significant at $\mathrm{P} \leq 0.05$. 
Table (4) illustrates the effect of ketogenic diet supplemented with different oils on kidney functions of diabetic rats. Injection with STZ significantly increase $(\mathrm{P} \leq 0.05)$ the level of urea and creatinine, compared to the control negative group. Feeding diabetic rats on ketogenic diet only or ketogenic diet supplemented with different oils caused a significant decrease $(\mathrm{P} \leq 0.05)$ in the mean values of urea and creatinine compared to the diabetic control group. No significant difference was noticed in serum urea and creatinine among the groups fed ketogenic diet supplemented with oils of either grape seed or fish or olive. Supplementation with different oils to the ketogenic diet significantly lowered the elevated level of creatinine compared to the diabetic rats that were fed on ketogenic diet only.

Table (4): Effect of ketogenic diets in serum urea and creatinine on diabetic rats

\begin{tabular}{|l|c|c|}
\hline \multirow{2}{*}{ Groups } & Urea & Creatinine \\
\cline { 2 - 3 } Control (-ve) & \multicolumn{2}{|c|}{ (mg/dl ) } \\
\hline Control (+ve) & $33.20 \pm 1.28^{\mathrm{d}}$ & $0.35 \pm .02^{\mathrm{d}}$ \\
\hline Diabetic+ keto diet & $58.00 \pm 2.35^{\mathrm{a}}$ & $0.91 \pm .03^{\mathrm{a}}$ \\
\hline Diabetic+ keto diet (grape seed oil) & $33.20 \pm 1.07^{\mathrm{b}}$ & $0.73 \pm .03^{\mathrm{b}}$ \\
\hline Diabetic+ keto diet ( fish oil) & $37.20 \pm 2.33^{\mathrm{bcd}}$ & $0.55 \pm .04^{\mathrm{c}}$ \\
\hline Diabetic+ keto diet (olive oil) & $40.20 \pm 1.69^{\mathrm{cc}}$ & $0.52 \pm .05^{\mathrm{c}}$ \\
\hline
\end{tabular}

Values were expressed as Means $\pm \mathrm{SE}$.

Values at the same column with different letters are significant at $\mathrm{P} \leq 0.05$.

The impact of ketogenic diet only or ketogenic diet supplemented with oils of either grape seed or fish or olive on lipids profile of diabetic rats was illustrated in Table (5). STZ injection to rats caused a significant increase $(\mathrm{P} \leq 0.05)$ in most of serum lipid parameters, while serum HDL-C was significantly lowered, compared to the healthy rats. Ketogenic diet only and ketogenic diet supplemented with oils of either grape seed or fish or olive significantly decreased $(\mathrm{P} \leq 0.05)$ the mean value of serum $\mathrm{TG}, \mathrm{TC}, \mathrm{LDL}-\mathrm{C}$ and VLDL-C, while serum HDL-C level was increased significantly, compared to the diabetic control group. It was obvious that, the treatments with ketogenic diet supplemented with oils of both fish and olive caused the highest beneficial effect in improving lipid profile in diabetic rats. 
Table (5): Effect of ketogenic diets on serum lipids profile of diabetic rats.

\begin{tabular}{|c|c|c|c|c|c|}
\hline \multirow{2}{*}{$\begin{array}{l}\text { Parameters } \\
\text { Groups }\end{array}$} & TG & TC & HDL-C & LDL-C & VLDL-C \\
\hline & \multicolumn{5}{|c|}{$(\mathrm{mg} / \mathrm{dl})$} \\
\hline Control (-ve) & $121.40 \pm 2.73^{\mathrm{d}}$ & $101.20 \pm 2.35^{\mathrm{d}}$ & $51.60 \pm 1.63^{\mathrm{a}}$ & $25.32 \pm 1.39^{\mathrm{d}}$ & $24.28 \pm 0.55^{\mathrm{d}}$ \\
\hline Control (+ve) & $221.40 \pm 1.81^{\mathrm{a}}$ & $207.80 \pm 2.87^{\mathrm{a}}$ & $41.20 \pm 3.26^{\mathrm{b}}$ & $122.32 \pm 2.88^{\mathrm{a}}$ & $44.28 \pm 0.36^{\mathrm{a}}$ \\
\hline $\begin{array}{l}\text { Diabetic+keto } \\
\text { diet }\end{array}$ & $153.60 \pm 3.25^{b}$ & $129.60 \pm 1.50^{\mathrm{b}}$ & $44.00 \pm 1.82^{\mathrm{b}}$ & $54.88 \pm 2.88^{b}$ & $30.72 \pm 0.65^{b}$ \\
\hline $\begin{array}{l}\text { Diabetic+ keto } \\
\text { diet (grape seed } \\
\text { oil) }\end{array}$ & $144.60 \pm 3.49^{c}$ & $120.80 \pm 1.69^{c}$ & $45.40 \pm 1.63^{\mathrm{ab}}$ & $46.48 \pm 3.57^{\mathrm{c}}$ & $28.92 \pm 0.70^{\mathrm{c}}$ \\
\hline $\begin{array}{l}\text { Diabetic+keto } \\
\text { diet ( fish oil) }\end{array}$ & $138.40 \pm 2.50^{\mathrm{c}}$ & $116.60 \pm 3.75^{\mathrm{c}}$ & $47.60 \pm 1.57^{\mathrm{ab}}$ & $41.32 \pm 2.94^{\mathrm{c}}$ & $27.68 \pm 0.50^{\mathrm{c}}$ \\
\hline $\begin{array}{l}\text { Diabetic+keto } \\
\text { diet ( olive oil) }\end{array}$ & $137.40 \pm 1.72^{\mathrm{c}}$ & $118.60 \pm 1.83^{c}$ & $46.40 \pm 2.46^{\mathrm{b}}$ & $44.72 \pm 2.60^{c}$ & $27.48 \pm 0.34^{\mathrm{c}}$ \\
\hline
\end{tabular}

Values were expressed as Means $\pm \mathrm{SE}$.

Values at the same column with different letters are significant at $\mathrm{P} \leq 0.05$.

\section{Discussion:}

Recently, the very low-calorie ketogenic diet has been highlighted in obesity management and its comorbidities (Merra et al., 2016). It is an effective way to lose weight, as they promote a non-atherogenic lipid profile, decreased insulin resistance and improved blood glucose levels (Merra et al., 2016 and Abbasi, 2018). On the basis of the results in the present study, KD showed an improvement in blood levels of glucose and insulin in diabetic rats, which is in agreement with previous studies Abdurrachim et al. (2019) who reported that KD lowered blood glucose and improved insulin levels. Moreover, Hallberg et al. (2018) and Rosenbaum et al. (2019) reported that the use of VLCKD resulted a significant decrease in the level of triglycerides, glucose and the degree of liver steatosis while improve insulin levels. Some studies on animals have also shown that the KD can prevent the development of diabetes using STZ in rats (Al-Khalifa et al., 2009 and Al-Khalifa et al., 2011). Also, Guo et al. (2020) stated that the KD improved both glycemic control and insulin sensitivity while decreased the degree of obesity in diabetic mice.

Serum glucose was increased in diabetic rats, while after the administration of KD supplemented with different oils the blood glucose was reduced which may be due to the protection of $\beta$-cells in pancreas to produce insulin that enhance glycogen synthase (Choudhury et al., 2017). These results are compatible with the results of Irandoost et al. (2013) who reported that consumption of grape seed oil (GSO) in overweight / obese women appears to enhance insulin sensitivity. On the other hand, there is no side effects 
mentioned for the effect of GSO in experimental diabetic rats. Moreover, Shaker et al. (2018) who mentioned that GSO plays an important role in treating diabetes mellitus and complications.

Furthermore, fish oil supplementation to the $\mathrm{KD}$ results in restoring blood lipid and glucose levels compared with KD alone (Zulyniak et al., 2013). Iizuka et al. (2018) found that addition of FO to low-dose pioglitazone effectively improved signs of type 2 diabetes in aged mice. Moreover, Parveen et al. (2019) stated that vegetables and fish oils are potent antidiabetic agent and beneficial for the regulation of diabetes-related disorders such as hyperglycemia, dyslipidemia and kidney damage induced by STZ in type 2 diabetic rat model. Hua et al. (2020) and Souza et al. (2020) found that FO supplementation is effective in enhancing insulin sensitivity and glycemic control in patients with overweight / obese and T2DM.

Al Jamal and Ibrahim, (2011) and Yousaf et al. (2014) noticed that virgin olive oil improved lipid profiles and blood glucose levels in STZ-induced diabetic rats which is in agreement with the results of the present study. This is due to the ability of phenolic compounds and monounsaturated fatty acids such as oleic acid to decrease the concentration of blood sugar by raising insulin sensitivity in cells (Alkhatib et al., 2018). Guasch-Ferre et al. (2015) mentioned that VOO lowered the risk of T2DM by $40 \%$ in patients with a high CVD risk. Also, Schwingshack et al. (2017) and Tsartsou et al. (2019) showed that olive oil consumption can improve blood glucose and lipid profile in diabetic patients.

Regarding to liver enzymes, the results of this study showed that the STZ induced a significant increase in the activity of serum AST and ALT. But, KD supplemented with either GSO or FO or OO caused significant improvement in liver function. Several studies have reported that GSO has hepatoprotective properties, among them the study of Khudair and Aldabaj, (2015) and Mokhtar et al. (2016) noticed that the oral administration of GSO showed significant decreases in serum AST and ALT activities. Ismail et al. (2016) demonstrated that GSO exhibits protective effects on acute liver damage caused by $\mathrm{CCL}_{4}$ in $\gamma$-irradiated rats. Also Atasever et al. (2019) reported that GSO reduced increased activities of liver enzymes because of its antioxidant properties.

Furthermore, results of the present study revealed that feeding diabetic rats with KD supplemented with FO restored the liver and kidney functions to normal. Metwally et al., (2011) showed that FO may have therapeutic potentiality for improving hepatic and renal functions in rats. Hassanen and Ahmed, (2015) showed that treatment with FO, VOO and their combinations exhibited improvement in liver functions and reduced the severity of liver injury. These results may be attributed to the presence of omega-3 fatty acids 
that have significant beneficial effects on liver regeneration. Al-Okbi et al. (2018) found that FO was the most effective treatment for improving AST and ALT.

Addition of virgin olive oil to the KD improved both kidney and liver functions which was in agreement with Santangelo et al. (2016) who demonstrated that extra-virgin olive oil consumption significantly reduced fasting plasma glucose, preserved hepatic and renal tissue from damages in diabetic rats. Lama et al. (2017) and Rezaei et al. (2019) showed that VOO limits insulin resistance and improved liver function.

Yanarates et al. (2008) found that the grape seed proanthocyanidins extracts (GSPE), considerably reduced serum urea and creatinine of diabetic rats. These results are matched with our findings. Also, Alshubaily et al. (2018) showed that GSO restored liver and kidney functions. The hepatic and renal protective effect of GSO is probably due to its antioxidant properties. Moreover, Albrahim and Robert, (2020) reported that grape seed extract could serve as the basis for developing improved chemopreventive or therapeutic kidney injury strategies.

Furthermore, Abd El-Azime et al. (2014) showed that FO could have the potential to improve hepatic and renal functions in irradiated rats. Wong et al. (2010) and Al-Okbi et al., (2018) found that FO supplementation substantially decreased serum creatinine levels in Type 2 DM patients. Alazawi and Almahdawi, (2018) found that using olive oil, it reduces the level of glucose and improve the health of the patient by repairing the damage in beta pancreatic cells, because of containing olive oil polyphenols it reduces the level of urea and maintains its normal level against changes in the body.

The results of this study showed that concentrations of TC, TG, LDL-C and VLDL-C in diabetic rats increased, while HDL-C decreased. This may be attributed to lipolysis in adipose tissue which in turn cause hyperlipidemia (Liu et al., 2019). Feeding rats on ketogenic diet and KD containing either GSO or FO or OO have led to further decrease in all lipid parameters except for HDL-C which increased non- significantly. This is consistent with the results of Rosenbaum et al. (2019) and Abdurrachim et al. (2019) who reported that KD lowered lipid profile. These results confirmed with Ng et al. (2016) who found that the KD decreased plasma triglyceride levels while increased serum HDL-c in mice. Moreover, Asadi et al. (2010) and Kim et al. (2010) mentioned GSO has an important role to play in improving the serum lipid profile. This results, along with that reported by Javadi et al. (2014) found that GSO could have beneficial effect on lowering LDL-c and triglyceride levels in diabetic rats. This results confirmed with Ranjbar-Zahedani et al. (2015) and 
Mokhtar et al., (2016) who specifies that GSO is effective in reducing TC, TG and LDL-c and increasing HDL-c.

Hassanen and Ahmed, (2015) and Kaseb and Biregani, (2016) showed that treatment with FO, VOO lowered lipid profile. These results, along with that reported by Wang et al. (2019) and Souza et al. (2020) demonstrate that FO can boost the lipid profile in rats with or without type 2 diabetes by reducing TG, TC, LDL, VLDL, and mildly elevating HDL-c. Consistent with previous studies Thilakavathi et al. (2019) who reported that omega 3 fish oil is a strong hypo-cholesterolemic agent.

Khan et al., (2107); Alazawi and Almahdawi, (2018) and Tsartsou et al. (2019) showed that EVOO a reduction of $14-25 \%$ in plasma lipids with an increase of $8-12 \%$ in HDL-c, which concludes that EVOO is effective in reducing lipid profile levels in type 2 diabetic dyslipidemia. Also, Simon et al. (2019) indicates that replacing high fat diet with OO may recover normal blood cholesterol values due to the presence of monounsaturated fatty acids and antioxidants (Alazawi and Almahdawi, 2018). Phenolic compounds in OO have also been related to increased levels of HDL-c (Servili et al., 2013). Memon et al. (2018) reported that the natural remedies Phyto therapy such as OO plays an important part in the treatment of dyslipidemia and control the serum TC and TG levels in type - II diabetic patients.

\section{Conclusions}

A ketogenic diet (KD) is a viable and safe nutritional plan for diabetic patients especially when supplement with oils of either grape seed or fish and virgin olive. When consuming ketogenic diets, careful choice of foods that will provide the necessary micronutrients is of paramount importance. KD successfully improved homeostasis of glucose in diabetic rats. It was concluded that, KD is a healthy foods and adjuvant therapy for diabetes in the future. 


\section{References:}

Abbasi, J. (2018): Interest in the ketogenic diet grows for weight loss and type 2 diabetes. JAMA. 319(3):215-217. doi:10.1001/jama.2017.20639.

Abd El-Azime, AS.; Hussein, EM and Ashry, OM. (2014): Synergestic effect of aqueous purslane (Portulaca oleracea L.) extract and fish oil on radiationinduced damage in rats. Int J Radiat Biol. 90 (12):1184-90.

Abdurrachim, D.;Teo, XQ.; Woo, CC.; Ong, SY.; Salleh, NF.; Lalic, J.; Tan, RS and Lee, PTH. (2019): Cardiac metabolic modulation upon lowcarbohydrate low-protein ketogenic diet in diabetic rats studied in vivo using hyperpolarized 13C pyruvate, butyrate and acetoacetate probes. Diabetes Obese Metab. 21:949-960. doi: 10.1111/dom.13608.

Al-Hariri, MT. (2012): Comparison the rate of diabetes mellitus induction using streptozotocin dissolved in different solvents in male rats. J Comp Clin Path Res.1:96-9.

Al -Jamal, AR and Ibrahim, A (2011): Effects of olive oil on lipid profiles and blood glucose in type2 diabetic patients. Int J Diabetes \& Metab. 19:192291.

Al-Khalifa, A.; Mathew, TC.; Al-Zaid, NS.; Mathew, E and Dashti, H. (2011): Low carbohydrate ketogenic diet prevents the induction of diabetes using streptozotocin in rats. Experimental and Toxicologic Pathology. 63;78:663-669. doi: 10.1016/j.etp.2010.05.008.

Al-Khalifa, A.; Mathew, TC.; Al-Zaid, NS.; Mathew, E and Dashti, HM. (2009): Therapeutic role of low carbohydrate ketogenic diet in diabetes. Nutrition. 25:1177-85. doi: 10.1016/j.nut.2009.04.004.

Al-Okbi, SY.; Mohamed, DA.; Hamed, TE.; Edris, AE and Fouda, K. (2018): Hepatic regeneration and reno-protection by fish oil, nigella sativa oil and combined fish oil/nigella sativa volatiles in CCl4 treated rats. J Oleo Sci. 1;67(3):345-353. doi: 10.5650/jos.ess 17204.

Alazawi, S.N and Almahdawi, ZM (2018): Effect of olive oil and sesame oil on some biochemical parameters in local male rabbits induced with diabetes. Tikrit Journal of Pure Science.23 (7): 36- 41. http://dx.doi.org/10.25130/tjps. 23.2018.108.

Albers, N.; Benderson, V and Warnick, G. (1983): Enzymatic determination of high density lipoprotein cholesterol, Selected Methods, Clin. Chem. 10:91-99.

Albert, BB.; Derraik, JG.; Brenan, CM.; Smith, GC.; Glarg, ML.; Smith, DC.; Hofman, PL and Cutfield, WS. (2014): Higher omega-3 index is associated with increased insulin sensitivity and more favourable metabolic profile in middle-aged overweight men. Sci Rep. 4 (6696):1-8. 
Albracht-Schulte, K.; Kalupahana, N.S.; Ramalingam, L.; Wang, S.; Rahman, S.M.; Robert-Mc Comb, J and Moustaid-Moussa, N. (2018): Omega-3 fatty acids in obesity and metabolic syndrome: a mechanistic update. J. Nutr. Biochem. 58; 1-16. https://doi.org/ 10.1016/ j.jnutbio. 2018.02.012

Albrahim, T and Robert, A. (2020): Renal protective effects of grape seed extract treatment against Eltroxin-induced hyperthyroidism, kidney damage, and oxidative stress in male mice. Environ Sci Pollut Res. https://doi.org/10. 1007/s11356-020-08210-8.

Alkhatib,A.; Tsang, C and Tuomilehto, J (2018): Olive oil nutraceuticals in the prevention and management of diabetes: from molecules to lifestyle. Int $\mathbf{J}$ Mol Sci. 19(7): 2024. doi: 10.3390/ijms19072024.

Alshubaily, F.; Jambi, E.; Khojah, S.; Balgoon, M.; Alzahrani, M. (2018): Prospective capa-bility of grape seed oil in face with the inverse influence of monosodium glutamate on liver and kidneys tasks. Australian Journal of Basic and Applied Sciences. 12(6): 48-52. doi: 10.22587/ajbas.2018.12.6.9.

Allain, CC.; Poon, LS. ; Chan, CS.; Richmond, W and Fu, PC. (1974): Enzymatic determin-ation of total serum cholesterol. Clin. Chem. 20: 470475.

Ambra, R.; Natella, F.; Lucchetti, S.; Forte, V.; Pastore, G. (2017): $\alpha$ Tocopherol, $\beta$-carotene, lutein, squalene and secoiridoids in seven monocultivar Italian extra-virgin olive oils. Int. J. Food Sci. Nutr.68: 538545.

Asadi, F.; Shahriari, A and Chahardah-Cheric, M. (2010): Effect of longterm optional ingest-ion of canola oil, grape seed oil, corn oil and yogurt butter on serum, muscle and liver cholesterol status in rats. Food Chem Toxicol. 48(8-9):2454-2457. doi: 10.1016/j.fct.2010. 06.012.

Atasever, A.; Alpay, A.; Ekebas, G and Gram, D. (2019): Effect of grape seed oil on chronic carbon tetrachloride-induced hepatic injury and determination of hepatic apoptosis in rats. Journal of Applied Life Sciences International. 21(1): 1-10. https://doi.org/10.9734/ jalsi/2019/v21i130097.

Bergmeyer, H.; Schreiber, $P$ and Wahlefeld. A. (1978): Optimization of methods for aspartate and alanine aminotransferase. Clinical Chemistry.24: 58-61. https://doi.org/10.1093/clinchem/ 24.1.58.

Boison, D. (2017): New insights into the mechanisms of the keto- genic diet. Current Opinion in Neurology. 30:187-192.

Burrin, JM and Price, CP. (1985): Measurement of blood glucose. Ann Clin Biochem. 22 (Pt 4):327-42.

Choudhury, H.; Pandey, M.; Hua, CK.; Mun, CS.; Jing, JK.; Kong, L.; Ern, LY.; Ashraf, NA.; Kit, SW.; Yee, TS.; Pichika, MR.; Gorain, B and Kesharwani, P.(2017): An update on natural compounds in the remedy of 
diabetes mellitus: A systematic review. J Tradit Complement Med. 8(3):361376. https://doi.org/10.1016/j.jtcme.2017.08.012.

Clark, PM and Hales, CN. (1994): How to measure plasma insulin, Diabet. Metab. Rev. 10: 79-90. doi: 10.1002/dmr.5610100203.

Covas, MI.; Nyyssonen, K.; Poulsen, HE.; Kaikkonen, J.; Zunft, HJ.; Kiesewetter, H. Gaddi, A.; de la Torre, R.; Mursu, J.; Baumler, H.; Nascetti, S.; Salonen, JT.; Fito, M.; Virtanen, J and Marrugat, J. (2006): The effect of polyphenols in olive oil on heart disease risk factors: a randomized trial. Ann Intern Med. 145:333-41.

Dehghan, M.; Mente, A.; Zhang, X.; Swaminathan, S.; Li, W.; Mohan, V.; Iqbal, R.; Kumar ,R.; Wentzel-Viljoen, E.; Rosengren, A.; Amma, L; Avezum, A.; Chifamba, J.; Diaz, R.; Khatib, R.; Lear, S.; LopezJaramillo, P.; Liu, X.; Gupta, R.; Mohammadifard, N.; Gao, N.; Oguz, A.; Ramli, AS.; Seron, P.; Sun, Y.; Szuba, A.; Tsolekile, L.; Wielgosz, A.;Yusuf , R.; Hussein-Yusufali, A.; Teo, KK.; Rangarajan, S.; Dagenais, G.; Bangdiwala, S.; Islam, S.; Anand, SS. and Yusuf, S. (2017): Associations of fats and carbohydrate intake with cardiovascular disease and mortality in 18 countries from five continents (PURE): a prospective cohort study. Lancet,390(10107):2050-2062.

Emsley, R., Dunn, G and White, I. (2010): Mediation and moderation of treatment effects in randomized controlled trials of complex interventions. Stat Methods Med Res. 19: 237-270. doi: 10.1177/0962280209105014.

Fossati, $P$ and Praneipe, L. (1982): Serum triglycerides determined colorimetrically with an enzyme that produces hydrogen peroxide. Clin Chem. 28(10):2077-80. doi:10.1093/clinchem/ 28.10.2077.

Fruchart, GG. (1982): LDL-cholesterol determination after separation of low density lipoprotein. Rev Fr Des Laboratories. 103(7):117.

Ghauri, AO.; Ahmad, S.; Rehman,T.; Bilal, M.; Arshad, MA and Abbasi, WM. (2020): Hypoglycemic and hypolipidemic effects of a poly herbal formulation in streptozotocin induced diabetic rats. Indian Journal of Traditional Knowledge,19(1);137-144.

Gonzalez, M. (2007): Hypoglycemic activity of olive leaf. J. Planta Med; 58: 313-315. doi: 10. 1055/s-2006-961538.

Gregg, EW and Shaw, JE. (2017): Global health effects of overweight and obesity. N Engl J Med 377(1):80-81. doi: 10.1056/NEJMe1706095.

Guasch-Ferre, M.; Hruby, A.; Salas-Salvado, J.; Martinez-Gonzalez, MA.; Sun, Q.; Willett, WC and Hu, FB. (2015): Olive oil consumption and risk of type 2 diabetes in US women. Am J Clin Nutr. 102:479-486.

Guo,Y.; Zhang,C.; Luo, M.; You, Y.; Zhai, Q.; Shang, F.; Yong Xia, Y and Luo, S. (2020): Ketogenic diet ameliorates cardiac dysfunction via balancing 
mitochondrial dynamics and inhibiting apoptosis in type 2 diabetic mice. Aging and Disease.11 (2):229-240. doi: 10.14336/AD.2019.0510.

Hallberg, SJ. ; McKenzie, AL.; Williams, PT.; Bhanpuri, NH.; Peters, AL.; Campbell, WW.; Hazbun, TL.; Volk, BM.; McCarter, JP.; Phinney, SD and Volek, JS. (2018): Effectiveness and safety of a novel care model for the management of type 2 diabetes at 1 year: an open-label, non-randomized, controlled study. Diabetes Ther. 9 (2): 583-612.

Hassanen, $\mathbf{N}$ and Ahmed, $M$ (2015): Protective effect of fish oil and virgin olive oil on diethylnitrosamine toxicity in rats. International Journal of Nutrition and Food Sciences.4, (3): 388-396. doi: 10.11648/j.ijnfs.20150403.27.

Hua, L.; Lei, M.; Xue, S.; Li, X.; Li, S and Xie, Q. (2020): Effect of fish oil supplementation combined with highintensity interval training in newly diagnosed nonobese type 2 diabetes:a randomized controlled trial. J. Clin. Biochem. Nutr. 66 (2);146-151. doi: 10.3164/jcbn.19-64.

Irandoost, P.; Ebrahimi-Mameghani, $M$ and Pirouzpanah, S. (2013): Does grape seed oil improve inflame-mation and insulin resistance in overweight or obese women? Int J Food Sci Nutr. 64 (6): 706- 710.

Iizuka, Y.; Kim, H.; Hirako, S.; Chiba, K.; Wada, M and Matsumoto, A. (2018): Benefits of combination low-dose pioglitazone plus fish oil on aged type 2 diabetes mice. J Food Drug Anal.26(4):1265-1274.

Ismail, AF.; Salem, AA and Eassawy, MM. (2016): Hepatoprotective effect of grape seed oil against carbon tetrachloride induced oxidative stress in liver of $\gamma$-irradiated rat. J Photochem Photobiol. B;160:1-10.

Javadi, S.; Eftekhari, A and Farshid, A. (2014): The effects of grape seed oil on histopathology-cal changes of the pancreas, liver and plasma lipids in streptozotocin induced diabetic rats. The J Urmia University of Medical Sciences. 25(7): 606-615. http://eprints.umsu.ac.ir/id/eprint/ 3283.

Kaseb, F and Biregani, AN. (2016): Effects of olive oil and grape seed oil on lipid profile and blood pressure in patients with hyperlipidemia: A randomized clinical trial. Food and Nutrition Sciences. 7:682-688.

Khan, TM.; Iqbal, S and Rashid, MA.(2017): Comparison of lipid lowering effect of extra virgin olive oil and atorvastatin in dyslipidaemia in type 2 diabetes mellitus. J Ayub Med Coll Abbottabad. 29(1):83-86.

Khudair, $K$ and Aldabaj, A. (2015): Effect of grape seed oil on hepatic function in adult male rabbits treated with sodium fluoride (Part-II). Advances in Animal and Veterinary Sciences. 3: 550-558.

Kim, D.; Jeon, G.; Sung, J.; Oh, S.; Hong, H and Lee, J. (2010): Effect of grape seed oil supplementation on plasma lipid profiles in rats. Food Sci Biotechnol. 19 (1): 249-252. 
Koppel, SJ and Swerdlow, RH. (2018): Neuroketotherapeutics: A modern review of a centuryold therapy. Neurochemistry International. 117:114-125.

Lai, X.; Kang, X.; Zeng, L.; Li, J.; Yang, Y and Liu, D. (2014): The protective effects and genetic pathways of thorn grape seeds oil against high glucose-induced apoptosis in pancreatic $\beta$-cells. BMC Complement Altern Med. 14:10.

Lama, A.; Pirozzi, C.; Mollica, MP.; Trinchese, G.; Di Guida, F.; Cavaliere, G.; Calignano, A.; Mattace Raso, G.; Berni Canani, R and Meli, R.(2017): Polyphenol-rich virgin olive oil reduces insulin resistance and liver inflammation and improves mitochondrial dysfunction in high-fat diet fed rats. Mol. Nutr. Food Res. 61 (3):1-12. doi: 10.1002/mnfr.201600418.

Larsen, K. (1972): Creatinine assay in the presence of protein with LKB 8600 reaction rate analyser. Clin Chim Acta.38:475-6.

Liu, Q.; Xie, Y.; Qu, L.; Zhang, M and Mo, Z. (2019): Dyslipidemia involvement in the development of polycystic ovary syndrome. Taiwanese Journal of Obstetrics \& Gynecology. 58(4):447-453.

Matthaus, B. (2008): Virgin grape seed oil: Is it really a nutritional highlight? Eur. J. Lipid Sci. Technol. 110: 645-650.

Memon, AR.; Ghanghro, AB.; Shaikh, IA.; Qazi ,N.; Ghanghro, IH and Shaikh, U. (2018): Effects of Olive Oil and Garlic on Serum Cholesterol and Triglycerides levels in the Patients of Type-II Diabetes Mellitus. J Liaquat Uni Med Health Sci. 17(02):101-5. doi: 10.22442/jlumhs. 181720559.

Merra, G.; Miranda, R.; Barrucco, S.; Gualtieri, P.; Mazza, M.; Moriconi, E.; Marchetti, M.; Chang, TF.; De Lorenzo, A and Di Renzo, L. (2016): Very-low-calorie ketogenic diet with amino acid supplement versus very low restricted-calorie diet for preserving muscle mass during weight loss: a pilot double-blind study. Eur Rev Med Pharmacol Sci. 20(12):2613-2621.

Metwally, NS.; Kholeif, TE.; Ghanem, KZ.; Farrag, ARH.; Ammar, NM and Abdel-Hamid, AHZ. (2011): The protective effects of fish oil and artichoke on hepatocellular carcinoma in rats. European Review for Medical and Pharmacological Sciences. 15: 1429-1444.

Mokhtar,R.; El-Banna,N and Haggag, M. (2016): Protective effect of grape seed oil on hypercholesterolemia in rats. International Journal of Nutrition and Food Sciences. 5 (5); 310-317. doi: 10.11648/j.ijnfs.20160505.11.

Naveen, $J$ and Baskaran, V (2018): Antidiabetic plant-derived nutraceuticals: A critical review. European Journal of Nutrition, 57(4):1275-1299.

(NCD-RisC) NRFC (2016): Worldwide trends in diabetes since 1980: a pooled analysis of 751 population-based studies with 4.4 million participants. 
Lancet. $\quad 387(10027): 1513-1530$. 6736(16)00618-8.

https://doi.org/10.1016/S0140-

Ng Tang Fui, M.; Prendergast, LA.; Dupuis, P.; Raval, M.; Strauss, BJ.; Zajac, JD and Grossmann, M. (2016): Effects of testosterone treatment on body fat and lean mass in obese men on a hypo caloric diet: a randomized controlled trial. BMC Med.14(1):153. doi: 10.1186/ s12916-016-0700-9.

Nylen K, Likhodii S, Abdelmalik PA, Clarke J, Burnham WM (2005): A comparison of the ability of a 4:1 ketogenic diet and a 6.3:1 ketogenic diet to elevate seizure thresholds in adult and young rats. Epilepsia;46(8):1198-204.

Parveen, K.; Siddiqui, WA.; Arif, JM.; Kuddus, M.; Shahid, SMA and Kausar, MA. (2019): Evaluation of vegetables and fish oils for the attenuation of diabetes complications. Cell Mol Biol (Noisy-legrand).30;65(7):38-45. doi: 10.14715/cmb/2019.65.7.8.

Patton, CJ and Crouch, SR. (1977): Spectrophotometric and kinetics investigation of the Berthelot reaction for the determination of ammonia. Analytical Chemistry, 49, 464-469. doi:10.1021/ac50011a034.

Piaggi, P.; Vinales, KL; Basolo, A.; Santini, F and Krakof, J. (2018): Energy expenditure in the etiology of human obesity: spendthrift and thrifty metabolic phenotypes and energy-sensing mechanisms. J Endocrinol Invest.41(1):83-89.

Psaltopoulou, T.; Kosti, RI; Haidopoulos, D.; Dimopoulos, $M$ and Panagiotakos, DB. (2011): Olive oil intake is inversely related to cancer prevalence: a systematic review and a meta-analysis of 13,800 patients and 23,340 controls in 19 observational studies. Lipids Health Dis. 30;10:127.

Ranjbar-Zahedani, M.; Alinejad, N.; Zadeh, S and Mazloom, Z. (2015): Comparison of the effects of edible oils: rice bran, grape seed, and canola on serum lipid profile and paraoxonase activity in hyperlipidemic rats. Int Cardiovasc Res J. 9 (1): 28-33.

Reeves, PG.; Nielsen, FH and Fahmy, GG. (1993): AIN-93. Purified diets for laboratory rodents: Final report of the American Institute of Nutrition adhoc wriling committee on the reformulation of the AIN-76 A Rodent diet. J. Nutrition.123: 1939-151. doi: 10.1093/jn/ 123. 11.1939.

Rezaei, S.; Akhlaghi, M.; Sasani, MR and Barati Boldaji, R. (2019): Olive oil lessened fatty liver severity independent of cardiometabolic correction in patients with non-alcoholic fatty liver disease: A randomized clinical trial. Nutrition.57:154-161. doi: 10.1016/j.nut.2018.02. 021.

Rosenbaum, M.; Hall, KD.; Guo, J.; Ravussin, E.; Mayer, LS.; Reitman, ML.; Smith, SR.; Walsh, TB and Leibe, RL. (2019): Glucose and Lipid Homeostasis and Inflammation in Humans Following an Isocaloric Ketogenic Diet. Obesity. (27) 6: 971-981. doi: 10.1002/oby. 22468. 
Santangelo, C.; Filesi, C.; Vari, R.; Scazzocchio, B.; Filardi, T.; Fogliano,V.; D’Archivio, M.; Giovannini,C.; Lenzi,A.; Morano,S and Masella, R. (2016): Consumption of extra-virgin olive oil rich in phenolic compounds improves metabolic control in patients with type 2 diabetes mellitus: a possible involvement of reduced levels of circulating visfatin. J Endocrinol Invest. 39:1295-1301. doi: 10.1007/s40618-016-0506-9.

Schwingshack, L.; Lampousi,A-M.; Portillo, MP.; Romaguera, D.; Hoffmann, G and Boeing, H. (2017): Olive oil in the prevention and management of type 2 diabetes mellitus: a systematic review and metaanalysis of cohort studies and intervention trials. Nutrition \& Diabetes. 7(4): 1-6. doi: 10.1038/nutd.2017.12.

Servili, M.;Sordini, B.; Esposto, S.; Urbani, S.; Veneziani, G.; Di Maio, I.; Selvaggini, $R$ and Taticchi, A. (2013): Biological activities of phenolic compounds of extra virgin olive oil. Antioxidants (Basel).20;3(1): 1-23.

Shaker,TA.; Salim , H and Saeed, M (2018): Effects of grape seeds oil on the antioxidants of alloxan induced diabetes in rats. Tikrit Journal of Pharmaceutical Sciences 13(1).

Simon, L; Saez Lancellotti, T; Cortese, L; Veisaga, ML; Chantarasinlapin, P; Barbieri, A and Fornes, M. (2019): Olive oil addition to the high-fat diet reduces methylglyoxal (MG-H1) levels increased in hypercholesterolemic rabbits. J. Mediterranean Journal of Nutrition and Metabolism, 12(1):13-21.

Souza, DR.; Pieri, BLDS.; Comim, VH.; Marques, SO.; Luciano, TF.; Rodrigues, MS and De Souza, CT. (2020): Fish oil reduces subclinical inflammation, insulin resistance, and atherogenic factors in overweight/obese type 2 diabetes mellitus patients: A pre-post pilot study. J Diabetes Complications. 34(5):107553. doi: 10.1016/j.jdiacomp.2020.107553.

Taltavull, N.; Ras, R.; Marine, S.; Romeu, M.; Giralt, M.; Méndez, L.; Medina, I.; Ramos-Romero, S.; Torres, JL and Nogues, MR. (2016): Protective effects of fish oil on pre-diabetes: A lipidomic analysis of liver ceramides in rats. Food Funct. 7: 3981-3988.

Thilakavathi, A.; Pandian Arjun, $P$ and Ramesh Samiraj, R.(2019): Hypocholesterolemic effect of dietary fish oil in albino wistar rats. Research Journal of Pharmacy and Technology. 12 (9); 4161: 4164.

Tsartsou, E.; Proutsos, N.; Castanas, E and Kampa, M. (2019): Network meta-analysis of metabolic effects of olive-oil in humans shows the importance of olive oil consumption with moderate polyphenol levels as part of the mediterranean diet. Front. Nutr. 6:6;1-11.

Wallach, J. (1992): Interpretation of diagnostic tests. A synopsis of aboratory medicine, 5 th Ed. A little brown handbook, Boston. 
Wang, F.; Liu, HC.; Liu, XS.; Dong, SN.; Pan, D.; Yang, LG and Sun, GJ. (2019): Effects of $\omega-3$ polyunsaturated fatty acids from different sources on glucolipid metabolism in type 2 diabetic patients with dyslipidemia. Zhonghua $\mathrm{Yu}$ Fang Yi Xue $\mathrm{Za} \mathrm{Zhi}$ [Chinese journal of preventive medicine].6;53(6):570-575. doi: 10.3760/cma.j.issn.0253-9624.2019.06.006.

Wang, Z.; Zhang, Z.; Du, N.; Wang, K and Li, L. (2015): Hepatoprotective Effects of grape seed procyanidin B2 in rats with carbon tetrachlorideinduced hepatic fibrosis. Altern Ther Health Med.21(2): 12-21.

Wong, CY.; Yiu, KH.; Li, SW.; Lee, S.; Tam, S.; Lau, CP and Tse, HF. (2010): Fish-oil supplement has neutral effects on vascular and metabolic function but improves renal function in patients with Type 2 diabetes mellitus. Diabet Med. 27(1):54-60. doi: 10.1111/j.1464-5491. 2009.02869.x.

Yanarates, O.; Guven, A.; Sizlan,A.; Uysal, B.; Akgul,O.; Atim, A.; Ozcan, A.; Korkmaz, A and Kurt,E. (2008): Ameliorative effects of proanthocyanidin on renal ischemia/reperfusion injury. Ren. Fail. 30(9): 931.

Yousaf, MJ.; Naveed, AK.; Khan, S.; Ahmed, T and Hussain Shah, SZ. (2014): The effect of olive- pomace oil on different blood parameters in streptozotocin induced diabetic rats. Pak Armed Forces Med J. 64 (3); 443446. https://pafmj.org/index.php/PAFMJ/article/view/1313.

Zulyniak, MA.; Perreault, M.; Gerling, C.; Spriet, LL and Mutch. DM. (2013): Fish oil suppl-ementation alters circulating eicosanoid concentrations in young healthy men. Metabolism. 62(8):1107-1113. 


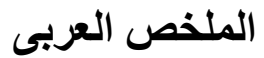

\section{دراسة التحكم في نسبة جلوكوز الام بواسطة النظام الغذائي الكيتونى المدعم بالزيوت المختلفة في الفئران المصابة بمرض السكرى من النوع الثاني}

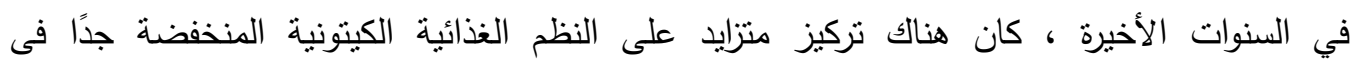

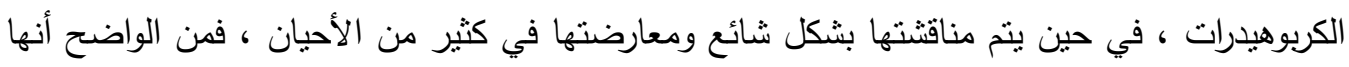

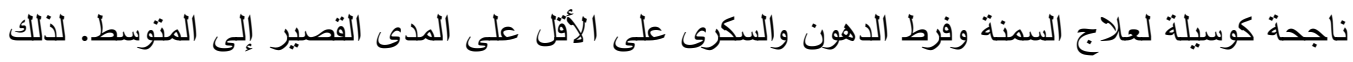

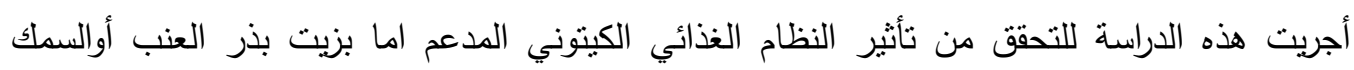

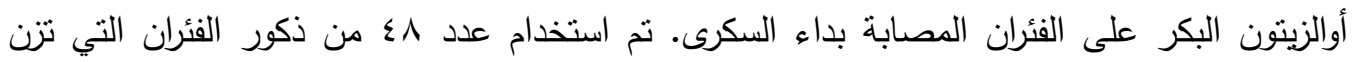

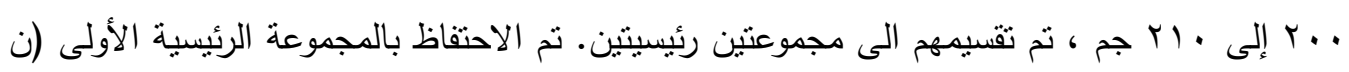

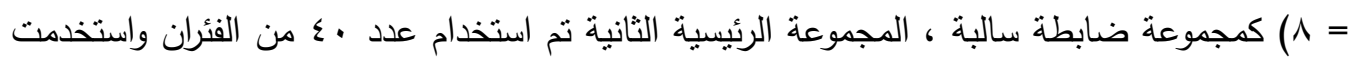

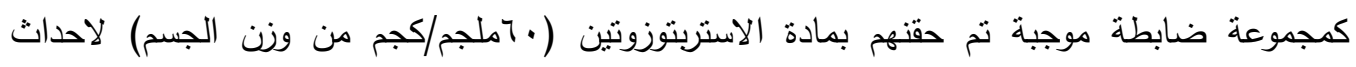

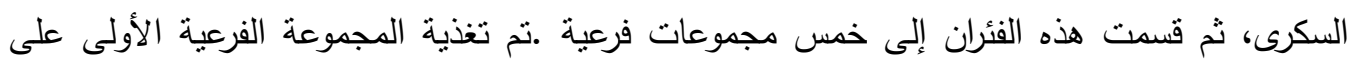

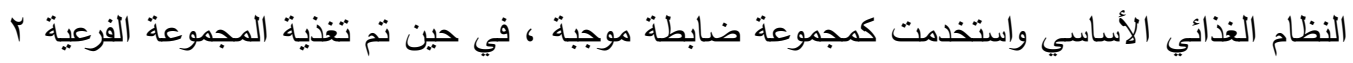

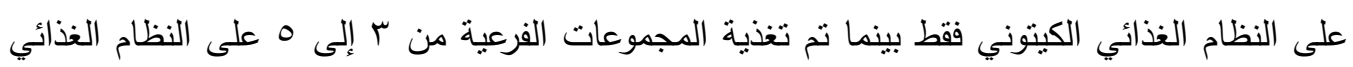

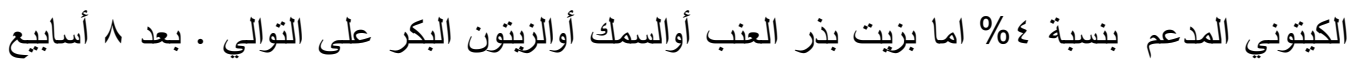
، تم ذبح الفئران وجمع عينات الدم للحصول على السيرم ـ اوضحت النتائج أن الفئران المعاملة الدئل

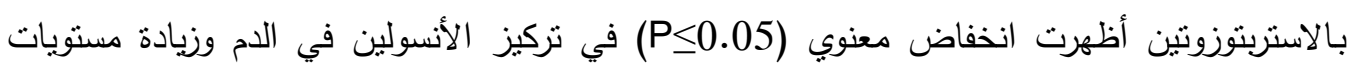

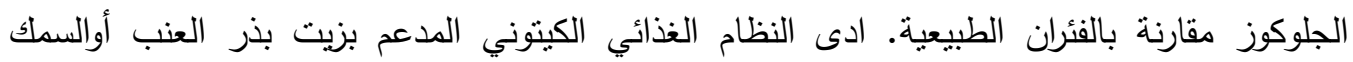

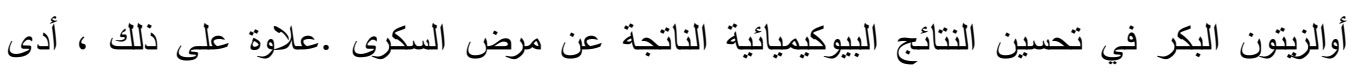
التخخل إلى إحداث تغييرات إيجابية في صورة دهون الدم وتحسين وظائف الكبد والكلى للفئران المعالجة مقارنة بالمجموعة الضابطة الموجبة. الخلاصة إن النظام الغذائي الكيتوني والكيتونى المدعم بزيت بذر دهر العنب أوالسمك أوالزيتون البكر هو نظام غذائي واعد محتمل لمرضى السكرى. 